\title{
The sources of Theophanes and the Syriac chroniclers.
}

It has long been known that for the $7^{\text {th }}$ and $8^{\text {th }}$ centuries a large portion of the work of Theophanes is derived from an Eastern source which was also used, directly or indirectly, by Michael the Syrian; and in $1897 \mathrm{I}$ published the concluding portion of a Syriac chronicle coming down to the year $846^{1}$ ), the author of which appeared to me, as I stated in the introduction, to have drawn from the same source. I then pointed out that down to the year 728 the chronicle contains notices of Byzantine history and military events, to which may be added accounts of natural phaenomena; but that from 728 to $785^{2}$ ) it deals with ecclesiastical affairs and the history of the Caliphs only, while from 785 to the end it is a mere list of Caliphs and patriarchs; from which it might be inferred that it was written about 785 and continued to 846, and that the author of 785 made use of a source which ended in or soon after 728. $\mathrm{H}$. Buk however in an article entitled 'Zur ältesten christlichen Chronographie des Islam,'s) maintains, as I understand him, that in the whole of the portion published in the $\mathrm{ZDMG}$, or at least in the last continuous fragment, beginning in 679 , no sources are used, but the chronicle consists of annalistic notices made at Charrhae ${ }^{4}$; and my object in the present article is first to show that the author used the same source as that which we find preserved in Theophanes and Michael, and then to attempt to throw some light on the very complicated question of the character of this source and the steps through which it came into the works of these two historians. On this latter point indeed I cannot hope to establish any final conclusion; but, as it is almost untrodden ground, the suggestions which I can make, even if they should be shown to be erroneous, may at least have the effect of stirring interest in the

1) ZDMG LI $569 \mathrm{ff}$. The whole has now been published in the Corpus Scriptorum Christianorum Orientalium (Chronica Minora pt. 2 p. $157 \mathrm{ff}$.).

2) Not 784 , as stated in the ZDMG.

3) Byz. Z. XIV $532 \mathrm{ff}$.

4) I am now satisfied that the chronicle was written in the monastery of Karthamin: see Introd. to new edition. 
subject and so paving the way by which some more certain result may be reached.

As to the use by the chronicler of $846^{1}$ ) of the TheophanesMichael source I think the following parallel passages will be sufficient proof. $\left.{ }^{2}\right)$

(1) "Anno 990, mense nisan, die 3, dominica Azymorum, hora 3, accidit terrae motus vehemens quo ruit Batnan Sarugi et ecclesia antiqua Edessae: et periit populus multus".

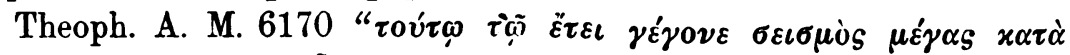

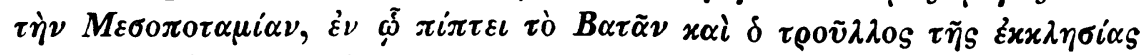

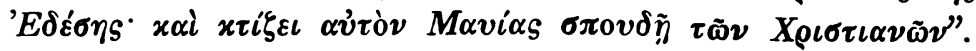

Mich. II p. 457 "En l'an 990, le jour de la fête de la Resurrection, à la $3^{\mathrm{me}}$ heure, il $\mathrm{y}$ eut un violent tremblement de terre. Batna de Seroug s'écroula, et aussi le ciborium de l'église d'Édesse et ses deux côtés. Mo'avia ordonna de la rebâtir".

(2) "Is (Abd al-Malik) composuit cum Romanis pacem 3 annorum, eisque solvebat tributum in singulos dies mille denarios et equum arabicum unum."

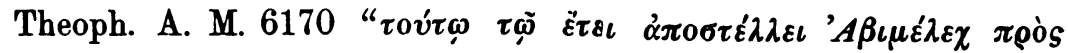

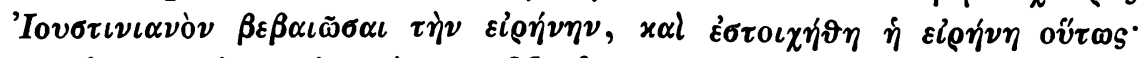

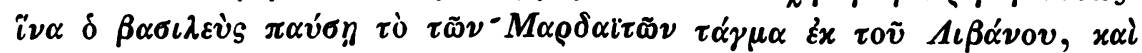

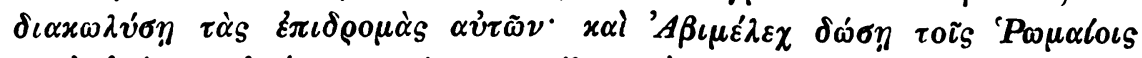

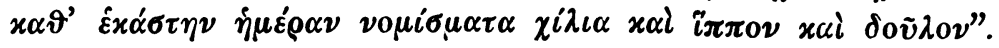

Mich. p. 467 "Abd el-Malik .... voulut faire la paix avec les Romains. Justinianus consentit à faire une trêve de 10 ans. Il fut convenu qu'il chasserait les Mardaites du Liban, qu'il empêcherait ses pillards d'envahir le pays des Taiyaye; st qu'en échange 'Abd el-M. donnerait aux Romains par jour mille dariques, un cheval et un esclave".

(3) "Anno 1006 exierunt exercitus Romanorum in vallem Antiochiae, et eis occurrit Dinar filius Dinar eosque destruxit; pauci eorum effugerunt et reversi sunt in dicionem Romanorum cum dedecora fama".

Mich. p. 470 "En l'an 1006 des Grees les Romains vinrent dans la plaine d'Antioche: une armée de Taigaye se réunit contre eux; elle détruisit la plupart d'entre eux et la reste: prit la fuite".

(4) "Anno 1008 cuderunt Arabes zuze et denarios quibus non cruces sed scripturae impressae sunt. Et anno sequenti fecit "Atiya descriptionem peregrinorum."

1) It is couvenient to cali him so ratber than the chronicler of $\mathbf{7 8 5}$.

2) I refer to the Chron. in M. Chabot's Latin version and to Mich. in his French version. The references to Mich. are to the pages of the translation. 
Mich. p. 473 "En l'an 1008 les Taiyaye commencèrent à frapper des dinars, de zouzê et des oboles, sur lesquels il n'y avait point d'image, mais seulement des inscriptions. En l'an 1009 eut lieu le recensement des étrangers par l'émir 'Ataya. Il en fit emmener beaucoup et les fit retourner dans leur pays".

(5) "Eodem anno (1015) exiit edictum et omnes porci necati sunt".

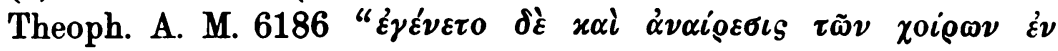
Evoia".

Mich. p. 475 "A cette époque 'Abd el-Malik, roi des Taiyaye, proscrivit de faire abattre les croix, et de tuer tous les cochons".

(6) "Anno 1024 mense sebat die 28, ad auroram feriae 3, fuit terrae motus in universis locis Syriae; destruxit et obruit homines innumeros; et fuit etiam locusta numerosa, et lues".

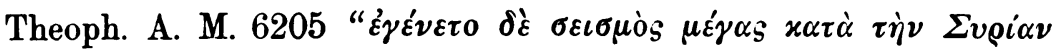
$\mu \eta \nu i \Pi_{\varepsilon \rho \iota \tau i \omega} x \eta^{\prime \prime}$.

Mich. p. 481, 482. "En l'an 1024 il y eut un tremblement de terre très violent, le 28 du mois de sebat (févr.); beaucoup d'endroits furent renversés dans la région d'Antioche, d'Alep et de Qennesrin..... En cette année survint la peste bubonique, et aussi l'arrivée des sauterelles en nombre infini".

(7) "Anno 1027 congregavit Soleiman copias et operarios, et gressi sunt per mare, et castrametati sunt in Asia; et expugnaverunt civitates 2, Sardes et Pergamum, aliaque castra; multosque occiderunt et captivos abduxerunt".

Mich. p. 487. "En l'an 1027 Maslama pénétra dans le pays d'Asie. Il s'empara de Pergame, de Sardes, et d'autres villes, dont il emmena les habitants en captivité".

(8) "Iussit (Yezid) ut delerentur omnes imagines et figurae in suo imperio sive aeneae, sive ligneae, sive lapideae sive coloribus depictae".

Mich. p. 489 "Yezid, roi des Taiyaye, ordonna d'arracher et de mettre en pièces les peintures et les statues ${ }^{1}$ ) de tout ce qui vit et se meut, des temples et des édifices, des parois, des poutres, des pierres; celles qui furent trouvées dans les livres furent lacérées".

(9) "Is (Hišam) plus quam reges sui praedecessores condidit domos, sata, officinas. Et eduxit ab Euphrate canalem ad irrigandum plantationes et sata quae ad oum fluvium instituerat".

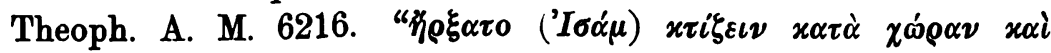

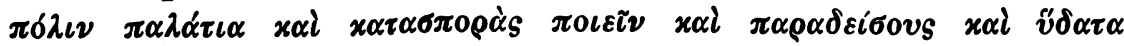
$\varepsilon x \beta \alpha^{\prime} \lambda \lambda \varepsilon \iota \nu "$.

1) The same words as those rendered 'imagines et figurae' above. 
Mich. p. 490. "Il (Hišam) fit amener des canaux de l'Euphrate au-dessus de Callinice, pour irriguer les récoltes et les plantations".

(10) "Anno 1037 ingressus est Maslama dicionem Romanorum: cepit Neocaesaream Ponti, et eam vastavit, et incolas eduxit captivos in Syriam".

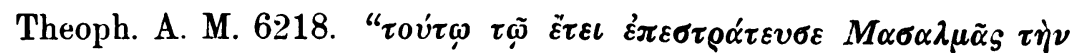

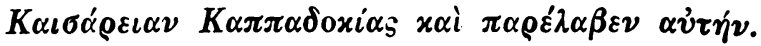

Mich. p. 490. "En cette année les Taiyaye assiégèrent Néocésarée de Pont; ils s'en emparèrent et la devastèrent complètement".

Of course many of these passages would, if taken alone, be of little weight; but, if we consider them altogether, the conclusion in favour of identity of origin appears irresistible; and, as the supposition that our chronicle is itself the source is precluded by the fact that the other accounts are often longer, it follows that all drew from an earlier work. The last notice in the Chronicle which deals with matters other than the history of the Caliphs and ecclesiastical affairs is that of the expeditions of Maslama against the Chazars which is placed under A. S. 1039 (728); but, as the two expeditions can hardly have taken place in the same year ${ }^{1}$ ), the end of this source may perhaps be placed a few years later. We are therefore probably justified in postulating a chronicle written about 730 which was used by the - chronicler of 846 , and in assuming that the chronicler of 846 used a source which we find also in Theophanes and Michael; but it does not necessarily follow that these two sources are the same. It is certainly true that the military notices do not show as close correspondence as the others, and that the last notice in which identity of origin seems certain is that of the buildings and irrigation works of Hisham; from which it may possibly be inferred either that the chronicler used two sources, one ending about 730 and the other about 725 , or that the chronicler of 730 used another chronicle written about 5 years earlier. But this is a minor point; and it may fairly be considered as established that the matter common to Theophanes and Michael is based upon a chronicle written between 724 and 731 .

The correspondence between Theophanes and Michael however does not end in 728 , but continues to 746 , as the following instances will show.

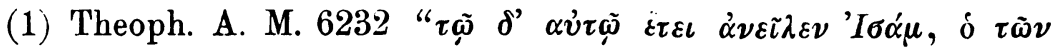

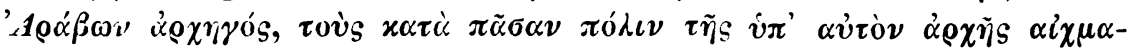

1) Theoph. places the $2^{\text {nd }}$ expedition 2 yrs., Mich. 3 yrs. later.

Byzant. Zeitschrift $x \vee 3$ u. 4 . 


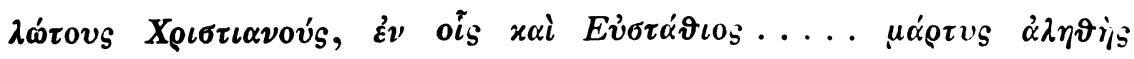

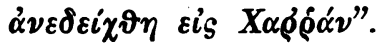

Mich. p. 501 "Cette même année (AS 1042) parut un décret de Hišam, roi des Taiyaye, et tous les prisonniers romains qui se trouvaient entre les mains des Taiyaye furent massacrés ..... Quand Eustathius et ses compagnons rendirent témoignage à Harran, on agita la question s'ils devaient être reconnus comme martyrs ou non".

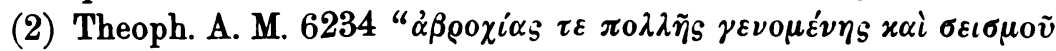

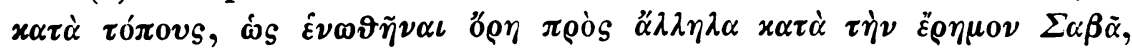

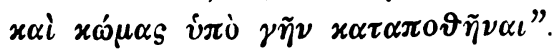

Mich. p. 506, 507 (AS 1056) "Les pluies firent défaut..... Il y eut de fréquents tremblements de terre, même dans le désert des Taiyaye. Des montagnes se rapprochèrent les unes les autres; des villages furent engloutis".

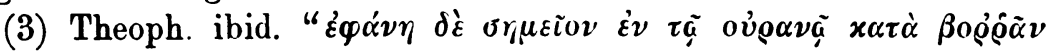

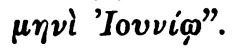

Mich. p. 507 "La même année (1056), au mois de haziran (juin) un signe apparut dans le ciel".

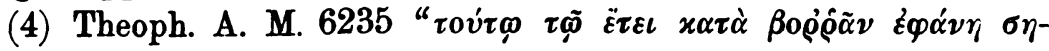

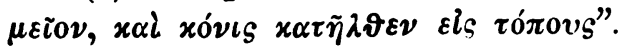

Mich. ibid. "L'année suivante (1057) apparut dans le ciel comme une demi-lune dans la région septentrionale ..... La même année une sorte de poussière remplissait toute l'atmosphère d'obscurité".

To these should perhaps be added the flood at Edessa (Theoph. A. M. 6232; Mich. p. 504); for, though Theophanes places it on $28 \mathrm{Feb}$. and Michael in March, this is easily explained if the original stated that it began on 28 Feb. and lasted till some day in March; possibly also the capture of Charsianum, which Theoph. ascribes to Maslama and Mich. to Mu'awiya (A. M. 6222; p. 507): to the mutilation and banishment of Peter of Damascus (A. M. 6234; p. 506) I shall recur later. Beyond the year 746 no correspondence can be traced ${ }^{1}$ ), and we may therefore assume that both drew, directly or indirectly, from a source which ended in or soon after this year.

The question now arises: have we any means of discovering what this source was? From Theophanes no information is to be got; but Michael tells us so much about his authorities that we might fairly hope to learn from him without much difficulty the source from which he borrowed so large an amount: unfortunately however the task proves

1) There are a few resemblances such as the notice of the removal of the people of Germanicea (Theoph. A. M. 6262; Mich. p. 526). 
on examination to be much less easy than it seems, and I cannot claim to have found any satisfactory solution. For the period 582-843 the work of Michael is mainly based on that of Dionysius the patriarch $^{1}$ ), whom he probably reproduces almost in full, and we find also mention of James of Edessa and John the Stylite of Litarba. ${ }^{8}$ ) Of these Dionysius is of course excluded by the fact that he wrote about 50 years after Theophanes, while the chronicles of James and John ended in $710^{3}$ ) and $736^{4}$ ) respectively, and are therefore too early. Other writers, mentioned in the preface, such as Ignatius of Melitene, wrote later than Dionysius. Unless therefore the author whom we seek was one whom Michael frequently used without once mentioning his name, which is very unlikely, we must assume that he did not use him directly at all, but found the extracts from him already existing in the work of Dionysius. Now the preface of Dionysius is preserved by $\mathrm{Michael}^{5}$ ), and in it is a list of chroniclers and historians whose works he proposes to supplement, among whom those which interest us are Daniel son of Moses of Tur 'Abdin, John son of Samuel of the Western Country (Syria), Theophilus of Edessa, and Theodosius of Edessa. Of these Theodosius was brother of Diony$\left.\operatorname{sius}^{6}\right)$ and is therefore too late. Daniel was Dionysius' maternal grandfather ${ }^{7}$ ) and is three times cited by Elijah of Nisibis ${ }^{8}$ ), the last time for an event of the year 748/9: as we cannot be certain to a year or two of the point to which the source extended, the fact that this is later than 746 is not fatal to identification, and the fact that the great star of Jan. 745, mentioned by Daniel, is recorded also by Theophanes ${ }^{9}$ ) is in its favour. On the other hand Dionysius says that the work of Daniel was of the nature of an ecclesiastical history rather than a chronography, which makes it difficult to think that this was the source from which the long narratives relating to Byzantine history which are common to Theophanes and Michael are derived. About Theophilus we have much more information. Dionysius tells us that he was a Chalcedonian and purposely omitted all mention of Jacobites; and a long account of him is given by Barhebraeus ${ }^{10}$ ), who states that he was a distinguished astrologer and as such gained the favour of the Caliph Al Mahdi, that he translated the Iliad and Odyssey into
1) III p. 112 .
2) II p. 357 .
3) II p. 482.
4) II p. 500. He died in 738 (Chron. of 846).
5) II p. 358 .
6) III p. 63, 64 .
7) II p. 477 .
8) Ed. Bacthgen, Abh. für die Kunde des Niorgenlandes Bd. 8.
9) A. M. 6236.
10) Chr. Syr. (ed. Bedjan) p. 126, 127; Chr. Arab. (ed. Pocock) p. 147, 148. 
Syriac, that he was a Maronite and wrote a Syriac chronicle in which he abuses the Jacobites, and that he died 20 days before Al Mahdi (15 July, 785). As Barhebraeus cites him for the length of time from Adam to Seleucus ${ }^{1}$ ), his chronicle must have began at the creation. He was also used by the Christian Arabic writer Mahbub of Hierapolis ${ }^{2}$; but, until Prof. Vasilyev's edition of this author appears, it is not possible to make use of the information which he supplies. 785 is a little late for the death of an author whose work did not extend much beyond 746 ; but this is not a very serious difficulty, while the two records of floods at Edessa which we find in Theophanes $^{3}$ ) are some support for the hypothesis of an Edessene source. It is here however necessary to go back to the Chronicle of 846 and consider whether the ecclesiastical notices contained in it are drawn from the same source as those of Michael, and, if so, whether this is identical with the source of the secular notices: if this be found to be so, it is clear that the author of 746 through whom these notices came to Michael cannot be the Maronite Theophilus. From the notices as to the succession of the patriarchs little can be inferred, since we should naturally expect to find agreement, and the correspondence, such as it is, extends beyond the year 731 , which, as we have seen above, is the latest date which can reasonably be given for the common secular source of Michael and the Chronicler of $846 .{ }^{4}$ ) On the other hand both agree in connecting the ordination of the patriarch Julian with that of bishop George of the Arabs $^{5}$ ); and upon the death of James of Edessa a similar notice occurs in both ${ }^{6}$ ), though with regard to this it must be noted that the words "Edessae.... monasterio" are a conjectural supplement to fill a lacuna in the MS of the

1) Chr. Syr. p. 37, Chr. Arab. p. 98 (cf. also p. 40).

2) Vasilyev, Agapij Manbidzhskij, khristianskij arabskij istorik X vjeka Viz. Vrem. XI (1904) $574 \mathrm{ff}$.

3) A. M. 6217, 6232: the earlier is not in Mich.

4) The only real discrepancies are as to the death of Severus Bar Mashke (Mich. A. S. 995, Chron. A. S. 994) and as to that of John of Callinicus (Mich. A. S. 1074, Chron. A. S. 1073). There is an apparent discrepancy as to the death of Athanasius III, which the text of Mich. places in A. S. 1039, while the Chronicler makes him present at a Synod in A. S. 1047. Barh. however, who follows Mich., places his death in A. S. 1051, and with this agrees Daniel of Tur 'Abdin quoted by Elijah of Nisibis; and I cannot doubt that there is an omission in Mich.'s text, whereby the true reference of the words 'in the same year' has been lost.

5) Mich. p. 474, Chron. p. 232.

6) Mich. p. 476, Chron. p. 283. 
Chronicle. The other ecclesiastical notices of the two authors are quite different. There is therefore not sufficient evidence to warrant us in assuming any common source for the ecclesiastical notices of Michael and the Chronicler; and, if there was such a source, there is no reason for identifying it with the source of the secular notices. As far as this matter is concerned therefore there is nothing which tells against the identification of the Chronicle of 746 with that of Theophilus. A more serious difficulty however remains behind. Barhebraeus cites Theophilus as giving the number of years from Adam to Seleucus as $519 i$, and this same number is given in the Maronite Chronicle recently published by me in the Corpus Script. Christianorum Orientalium $^{1}$ ), from which the conclusion appears irresistible that this chronicle is either the actual work of Theophilus or an earlier work incorporated by him; yet the latest fragments of this author, which extend from 659 to 664 , show little resemblance to the common portions of Theophanes and Michael. The earthquake of June 659 is indeed recorded by Theophanes (AM 6150) though not by Michael, and the statements that the Emperor Constans put his brother to death without cause, that he thereby incurred unpopularity and in consequence left the city, and that he was called a second Cain are found also in $\mathrm{Michael}^{2}$ ), and the second and third of these in Theophanes ${ }^{3}$ ): on the other hand in describing what followed Theophanes and Michael have a common account, which is quite different from that of the Maronite Chronicle, the Theoph.-Mich. source saying that he wished to make Rome his capital and took up his residence at Syracuse, whence he sent for his wife and sons, but the Byzantines would not let them go $^{4}$ ), while the Maronite says that he left the government to his son Constantine, took the Empress and the whole army and marched against the northern barbarians. Again of the long account of Yazid's campaign in Thrace which we find in the Maronite Chronicle there is not a word in either Theophanes or Michael, and the campaign of 'Abd Al Rahman in Asia is wholly omitted by Michael and dismissed in a sentence by Theophanes. ${ }^{5}$ ) The identification of the chronicler of 746 with Theophilus therefore, tempting though it is, can only be maintained by means of some complicated hypothesis, such as that the Maronite Chronicle is not a

1) Chronica Minora pt. 2 p. $43 \mathrm{ff}$; cf. also Nöldeke in ZDMG XXIX p. $82 \mathrm{ff}$. and F. Nan Opuscules Maronites.

2) II p. $446 . \quad 3)$ A. M. 6160.

4) Theoph. A. M. 6153, Mich. l. c.

5) A. M. 6156. 
source of Theophilus but only derived from the same source; and, if it is abandoned, it follows that the chronicler whom we are seeking must be the only remaining authority mentioned by Dionysius, John the son of Samuel, of whom we know nothing except that he lived in Syria, though, as Dionysius says nothing to the contrary, we may assume that he was a Monophysite and that he wrote in Syriac. Two other possibilities certainly remain, one that the chronicler of 746 was not used directly by Dionysius, but through Theodosius or John, the other that Dionysius does not name all his authorities in the preface. As to the first, the supposition that Dionysius should not have had access to any writer used by Theodosius, his own brother, or that, having access to him, he should not have cared to use him directly is, in so painstaking a writer, scarcely credible, while the difference between identifying the author whom we seek with the unknown John and making him a source of John is too slight to be worth discussing. As to the second, it may certainly be true that Dionysius does not give an absolutely exhaustive list of anthorities used by him: the quotation from the Nestorian Denhishu at Mich. III p. 20 must indeed be attributed to Michael; but the reference to the Chalcedonian writer who abuses Nicephorus (III p. 16) is probably taken from Dionysius, though he can hardly be identified with any of the authors mentioned in the preface. It is indeed somewhat hard to think that this writer can be other than Theophanes, whose work Dionysius may have seen but certainly did not use, as is shown by the fact that the correspondence between Michael and Theophanes closes at 746, and that the Byzantine notices found in Michael are full of blunders. But, whoever this Chalcedonian writer may have been, it is unlikely that he was habitually used by Dionysius, and the list given in the preface, though it may not give the name of every writer from whom anything whatever is taken, must be assumed to include that of one whom he uses so frequently as he does the chronicler of 746. This author therefore, if he was not Theophilus of Edessa, can hardly have been other than John the son of Samuel.

It still however remains to be considered by what means this chronicler came to be used by Theophanes. As he wrote in Syriac, Theophanes cannot have used him directly, as might also be inferred from the fact that Eastern notices are found in his work down to a much later date than 746, though he is not likely to have used two Eastern authorities. Now the last notice which seems to be derived from an Eastern source is that of the persecution of Christians by Al Mahdi given under A. M. 6272 (780); for later notices, such as 
those relating to the succession of the Caliphs, and those of the anarchy which followed the death of $\mathrm{Al}$ Rashid and of the destruction of the Palestinian monasteries, need not be drawn from any written source. The author whom he used therefore must be assumed to have written in or soon after 780; and, as he wrote in Greek, he can hardly have been other than a Melchite, as may also be deduced from the fact that from $\mathbf{7 4 2}$ to $\mathbf{7 5 6}$ he gives the history and succession of the Melchite patriarchs of Antioch. To this writer also may perhaps be ascribed the additions and corrections to the account of the treatment of a Chalcedonian bishop which is found under A. M. 6234 (see above p. 582) and from the resemblance to Michael seems to come from the chronicle of 746 , though the error by which he is called in Michael the Chalcedonian patriarch instead of bishop Peter of Damascus should perhaps be ascribed to Dionysius rather than to the earlier writer. In the account of the martyrdom of Eustace also (see above p. 581, 582) we may perhaps see Chalcedonian additions to a Jacobite narrative. The frequent references to Palestine and Jerusalem (A. M. 6238, 6241, 6243, 6264, 6272) seem to fix Palestine as the place of writing, and we may with much probability suppose that the work was brought to Constantinople by the monks who fled thither after the destruction of the Palestinian monasteries in 813 (Theoph. p. 499), from whom also Theophanes may have obtained such knowledge as he shows of Eastern affairs after 780.

To sum up, Michael used Dionysius (843-6), and Theophanes used a Palestinian Melchite author who wrote in Greek not long after 780 ; while both of these last used a chronicler who wrote not long after 746, whom there is some reason to identify with John the son of Samuel, though we cannot positively assert that he was not Theophilus of Edessa. This writer again used an author who wrote between 724 and 731 , who was also used by the chronicler of 846 , or rather the monk of Karthamin, whose chronicle, written in 785 , was continued to that year.

London.

E. W. Brooks. 